\title{
Consumers' Cultural Identity and Marketing of Derivatives of Intangible Cultural Heritage
}

\author{
Yijun Huang \\ Institute of Inheritance and Development of Maritime Silk \\ Road Culture \\ Quanzhou Normal University \\ Quanzhou, China 362000
}

\author{
Qinghua Lyu \\ Business School of Huaqiao University \\ Quanzhou, China 362021
}

\begin{abstract}
Cultural identity refers to an affirmative and positive evaluation in attitude towards cultural elements. In the age of emotional consumption, whether derivatives of intangible cultural heritage can obtain consumers' cultural identity will be crucial for the better integration of it in the daily life of the general public. Derivatives of intangible cultural heritage are social, regional, symbolic and cultural and have the congenital advantages of obtaining consumers' cultural identity. How to transform the product superiority into marketing advantage will have an important realistic value for the popularization of derivatives of intangible cultural heritage. Consumers' cultural identity possesses four dimensions, namely product cognition, group affiliation, emotional commitment and cultural self-esteem. Specific marketing measures can be developed correspondingly according to the characteristics of derivatives of intangible cultural heritage.
\end{abstract}

Keywords-cultural identity; derivatives of intangible cultural heritage; marketing

\section{INTRODUCTION}

Derivatives of intangible cultural heritage are products or services that base on resources of intangible cultural heritage, are designed, innovated and produced by production organizations such as inheritors or enterprises through traditional or modern techniques for usage and consumption and meet consumers' needs in aesthetics, spiritual pleasure, cultural experience and function. Under the premise of protection and non-excessive commercialization, derivatives can become the optimum medium for intangible cultural heritage to enter the public's life. The public will strengthen cognition and elevate identity in consumption, and inheritors of intangible cultural heritage and enterprises can obtain corresponding economic or spiritual benefits, forming the positive feedback cycle of protection and usage. In order to achieve the ideal effect, it has crucial influence that whether derivatives of intangible cultural heritage can obtain consumers' cultural identity. Derivatives of intangible cultural heritage are social, regional, symbolic and cultural and have the congenital advantages of obtaining consumers' cultural identity. How to transform the product superiority into marketing advantage will have an important realistic value for the popularization of derivatives of intangible cultural heritage. On the basis of sorting out literatures at home and abroad, this paper has systematically explained the concept and dimensions of consumers' cultural identity and analyzed the corresponding nature between derivatives of intangible cultural heritage and cultural identity under consumer context. In the end, marketing suggestions are put forward to enhance consumers' cultural identity according to characteristics of derivatives of intangible cultural heritage.

\section{CONNOTATION AND DIMENSIONS OF CONSUMERS CULTURAL IDENTITY}

\section{A. Definition of Cultural Identity}

The English word "identity", derives from Latin idem (namely "the same") and has revealed the relationship between "similarity" and "difference". "Similarity" (or sameness) and "difference" are two different aspects of identity. The same features of a person and the similarity between members of a group at the same time constitute the difference from others (or "them"). Identity further means individuals think they have the same or consistent aspects with objects and expect to keep the consistency to produce a sense of belonging. The objects identified can be nation, culture, occupation, some organization even the subject, so that different types of identification are divided, such as national identity, cultural identity, occupational identity, organizational identity and selfidentity. The so-called cultural identity will form when the objects identified by people are cultural elements such as cultural concept, cultural symbol, customs, moral principles and systems.

At present, no general definition on cultural identity exists in the academic circle. Some scholars emphasize cultural identity refers to a positive psychological link between individuals and some culture and an approval and belonging of the culture. For members in a group, cultural identity can be built through the consensus of individuals on the culture that embodies the main characteristics of the group and the social network connection between group members. For this point of view, cultural identity still has the essential connotation of similarity and sameness, so the common cultural elements can be shared among group members; in contrast, these group characteristics also reflect their unique identity that distinguishes them from other groups (Wan and Chew, 2013 [1]; Zheng Xiaoyun, 2008 [2]). Other scholars also affirm the relation between individuals and some culture or group, but are 
inclined to define cultural identity as an attitude evaluation, such as regard cultural identity as the degree that individuals accept some specific cultural characteristic and the affirmative cognition towards things and values that best reflect some group (Dong Qing, Hong Yan, 2015 [3]). Taiwan scholars ChiTsun Huang and Tsung-Chi Liu (2005) think cultural identity means consumers have different attitudes toward exotic culture in cognition, emotions and behaviors [4].

For the research purpose and needs, this paper defines consumers' cultural identity as: on the basis of judging the affirmative value of the cultural connotation or manifestation pattern of products or brands, consumers produce an attitude evaluation of emotions like favor, belonging and pride for the products or brands and their cultural identity.

\section{B. Dimension of Cultural Identity}

There are two views on the dimension of identity in the organizational and marketing fields: The first defines identity in cognitive category and pays attention to how consumers treat the "overlapping" between them and enterprises or brands on the cognitive level. For example, Brown et al. (2005) define consumers' enterprise identity as "the degree of overlapping of self schema and organization schema" [5], and Bagozzi and Dholakia (2006) regard consumers' brand identity as "the degree of overlapping of consumers' self-impression and brand image" [6]. They prefer to lay the emphasis of identity on consumers' perception of organization and brand and think other components like emotions and evaluations are only potential cause and effect of identity. The second thinks the nature of identity is multidimensional. For example, Edwards and Peccei (2007) hold the opinion that only understanding identity at the cognitive level has weakened the powerful explanation of social identity theory and failed to reflect its complexity [7]. Harquail (1998) also thinks the organization identity contains "the cognition of brain" and "inner emotions" [8]. The scholars all affirm the cognitive part of identity but they advocate individuals must evaluate and feel the correlation (with organizations, enterprises and brands) on the basis of social identity theory and the generating process of identity.

In terms of the dimension of cultural identity, multidimensional (cognition, emotion and evaluation) and onedimensional views exist in the academic world and no consensus has reached. Simply building identity on the cognitive level and ignoring other important dimension will be adverse to the complete construction of consumers' cultural identity. Mainstream opinions in the marketing field basically originate from social identity. That's to say, cultural identity contains multi-dimensional structures of cognition, emotions and evaluation. From the perspective of derivatives of intangible cultural heritage, consumers' cultural identity is not confined to the knowledge of these things' existence. It contains the favor and satisfaction of people when they deeply understand the traditional culture or heritage elements, even the self-esteem of Chinese people on the traditional culture, in order to completely cover the definition of cultural identity and better conform to the general behavior characteristics of consumers.

\section{CORRESPONDING NATURE BETWEEN DERIVATIVES OF INTANGIBLE CUlTURAL HERITAGE AND CULTURAL IDENTITY UNDER CONSUMER CONTEXT}

Derivatives of intangible cultural heritage contain special properties of sociality, regionalism, symbol and culture and are closely related to cultural identity. First of all, most derivatives of intangible cultural heritage originate from agricultural society. Its continuation and production principally depend on the inheritance of people from generation to generation in history, so it has specific historical inheritance. Some derivative of intangible cultural heritage will disappear once the inheritance activities between different generations or between master and apprentice. Therefore, derivatives of intangible cultural heritage have deep inheritance value on certain common cultural gene. All derivatives of intangible cultural heritage relate to human factors like "individuals" and "groups". Namely, derivatives of intangible cultural heritage have "social" characteristics and embody difference, diversity and individuality of social traditional culture, so that it is easily perceived by consumers.

In the second place, derivatives of intangible cultural heritage have certain influence or growth scope spatially and highlight an intense regional color. For example, the Southern Music performance in Quanzhou is mainly popular in regions involving Southern Fujian Dialect such as southern Fujian and Taiwan, while the performance of "Er Ren Zhuan" (a songand-dance duet popular in the Northeast of China) has a profound mass base in the Northeast of China. On the basis of inheriting regional natural environment and humanistic literacy, derivatives of intangible cultural heritage become an important part of the specific folk traditional cultural system of the region and exist in the region to influence consumers imperceptibly, possessing the natural advantage of obtaining the cultural identity of groups in the region. The consumption habits, consumption preferences and consumption ability of local people will always in turn influence the production, development, evolution and degradation of derivatives of intangible cultural heritage. For example, Li Xiao Cen and Zhu Xia (2017) observe the traditional crafts of intangible cultural heritage are in nature a local practical knowledge, the achievement closely related to geographic background and historical development and embody the relationship between human and nature. Local resources have provided natural materials for the traditional crafts, while different geographical conditions and national cultures have determined different styles of traditional crafts [10].

In the third place, as a constituent part of cultural product sequence, derivatives of intangible cultural heritage have a strong symbol property. Baudrillard addresses things are carriers that reflect social implication, social and cultural level, reflecting in the forms, materials, color, durability and allocation of space of things and full of the color of codes. The logic behind it is the common psychological perception of subjects toward the authenticity "denoted by symbols" [11]1617. Scholars propose intangible cultural heritage exists as the cultural symbol of people in certain area, and it "builds the symbol of meaningful world with collective consciousness via verbal sign and non-verbal sign" [12]. Diversified derivatives based on intangible cultural heritage have also inherited the 
symbolic nature of intangible cultural heritage. Particularly, the constant restatement of modern media for symbols or forms of intangible cultural heritage (the release of lists and inheritors of representative projects of intangible cultural heritage, the discussion of media on the modern existent crisis of intangible cultural heritage) has further strengthened the perception of social subjects on the cultural symbols of derivatives of intangible cultural heritage. For a specific region or cultural group, the consumption of derivatives of intangible cultural heritage makes them "jointly possess the same code and share the same symbols that are different from other groups" [13], and then they will obtain the cultural identity of some symbol.

In the last place, derivatives of intangible cultural heritage often become a part of cultural experience of people that live in specific region or belong to a specific group. Wan and Chew (2013) think individuals carry out social interaction and absorb cultural knowledge in groups and connect with cultural groups psychologically. Individuals and experience of some culture are accompanied by the formation of cultural identity. Therefore, the past has become a heritage of individuals and individuals find they are willing to be affiliated to some historical value and be loyal to the values in life (Gomzina, 2012) [14]. Pomian (2009) raises the opinion of connecting identity and past and emphasizes the importance of collective memories that have become heritages, "...Identity is closely linked with the past. Because of the existence of the linkage, when we speak of identity, we also refer to some things inherited from predecessors." [15] Derivatives of intangible cultural heritage have been important constituent parts experienced by people from generation to generation in life, culture, social interaction since the agricultural society. To keep vitality and influence, derivatives of intangible cultural heritage also need to continuously interact with the everchanging natural, social and cultural environment and live with people, nation and region involved in its growth and form cultural complex. With the growth of consumers' age and experience, people's social interaction will increase correspondingly and contact cultural space in their life. In the repeated social confirmation and self-consciousness introspection, cultural elements, knowledge and experience contained in derivatives of intangible cultural heritage will form a stable and lasting attitude system in consumers' brain in the idea of form and then further intensify the influence of cultural identity.

Since the sociality, regionalism, symbol and culture owned by derivatives of intangible cultural heritage have internally influenced consumers' cultural identity, then how can the mental mechanism produce? Oyserman (2007) thinks personal identity and social identity have contained all the images about future. The images have characteristics of motivation and have provided reasons for taking action or inhibiting action under specific situation, like providing scripts for insisting or interrupting actions. In other words, identity has supported objectives while objectives trigger behaviors. In the psychological process, Oyserman has introduced the concept of self-regulation. Self-regulation refers to an emotional and behavioral adjustment to keep a rational and positive selfperception when people make efforts to achieve the goal in a proper way in society. No matter whether individuals take action, self-regulation has connected the present and the future, current self and possible self, current behaviors and longerterm goal pursuit. Self-regulation has contained individuals' participation or inhibition in the current or on-going behaviors, in order to increase the probability of achieving goals subsequently. Therefore, self-regulation has aroused behavioral inhibition and behavioral activation systems [16]. Similarly, the influencing process of cultural identity can be explained as: Consumers unceasingly compare, judge and accept cultural elements of derivatives of intangible cultural heritage in the process of psychological adjustment, having produced positive attitude evaluation and influenced the subsequent behaviors like purchase, public praise and loyalty. According to the ABC attitude model in consumer behavior, cognition, emotions and behaviors influence each other. At present, most researches have thought cultural identity is an effective variable to influence consuming behavior. In this regard, improving consumers' sense of cultural identity will become an important marketing method to popularize derivatives of intangible cultural heritage.

\section{IMPROVE CONSUMERS' CULTURAL IDENTITY AND POPULARIZE DERIVATIVES OF INTANGIBLE CULTURAL HERITAGE}

According to the above-mentioned conclusion on the dimensions of cultural identity and the characteristics of derivatives of intangible cultural heritage, consumers' sense of cultural identity can be enhanced from product cognition, group affiliation, emotional commitment and cultural selfesteem. Inheritors of intangible cultural heritage and manufacturing enterprises can formulate corresponding marketing strategies from the following perspectives:

\section{A. Take Advantage of the Sociality of Derivatives of Intangible Cultural Heritage to Improve Consumers' Product Cognition}

The traditional derivatives of intangible cultural heritage have been rooted in the soil of agricultural society, but under the new social conditions, inheritors of intangible cultural heritage and enterprises have to expand the original relatively narrow spreading scope and obtain the cognition of more audiences. Specifically speaking, inheritors of intangible cultural heritage and enterprises can choose proper themes of intangible cultural heritage through deeply excavating cultural connotation and innovative manifestation forms, manufacture new creative products through excavation, sorting, processing and extraction to further elevate consumers' cognition on derivatives of intangible cultural heritage. For example, they can make use of characteristic folk customs and folk literature to develop derivatives like desk calendar, postcard, bookmark, emoji and cartoon and let derivatives of intangible cultural heritage enter the daily life of the public and then expand the spreading scope. In addition, they can promote through ways of shooting advertising videos, micro films and micro videos related to products of intangible cultural heritage and through media such as network, television and outdoor advertising. The key to market on the dimension of product cognition is to highlight the derivatives of intangible cultural heritage are 
unique, sole, non-renewable, irreplaceable and scarce. Items and products of intangible cultural heritage with a unique originality can obtain cultural sign power, sense of social identity and market competitiveness to get approval of consumers.

\section{B. Make Use of the Regionalism of Derivatives of Intangible Cultural Heritage to Enhance the Group Affiliation of Consumers}

People have the need to connect with others, so group affiliation can be understood as a group identity produced by people's needs to become a member of a specific group. For consumers, group affiliation shows the sense of belonging and identity of consumption groups in a specific region and embodies the regionalism of derivatives of intangible cultural heritage. For example, Matteucci (2015) mentions one of the purposes of tourists in participating in the experience consumption of intangible cultural heritage related to Flamenco in Seville of Spain is to obtain social status, reputation and cognition and distinguish from other social groups and then build self-identity [17].

Inheritors of intangible cultural heritage and enterprises can enhance consumers' sense of group affiliation through constructing community for the communication of fans of intangible cultural heritage and carrying out product marketing on social media. For example, popular patterns in modern society such as public course, public lecture, public performance that combines music and lecture, annual theme activities, sales of cultural shirts, platform construction of WeChat and Weibo can be used to integrate brand promotion, sales of derivatives and construction of network community to form brand community effect and word-of-mouth effect.

\section{Take Advantage of the Symbolism of Derivatives of Intangible Cultural Heritage to Improve Consumers' Emotional Commitment}

The establishment of commitment contains attitude and contract [18], and the emotional commitment of this paper places emphasis on attitude. The manifestation of emotional commitment is consumers' emotional response and emotional input (such as consumers produce emotions of satisfaction, novelty and correspondence) on derivatives of intangible cultural heritage. It establishes on the basis of the symbolic difference between derivatives of intangible cultural heritage and other products. Symbols of some group like historical memory, generation inheritance, emotional value and faith value make derivatives of intangible cultural heritage "be identified and specialized" through unique connection with concrete subjects. At this time, it bears the connotation of representing different status, reputation and traditions and arouses consumers" "obsession", "passion" or "highlights" toward derivatives of intangible cultural heritage [11]58-59. Therefore, emotional commitment will exist when consumers' feelings conform to the symbolic signs of derivatives of intangible cultural heritage.

Behaviors related to symbols can be divided into three types: The first is to apply symbols in combinations (such as speaking and writing); the second is to describe symbols and use rules (such as Meta language and grammar, etc.); the third is to produce new symbols [11]. Correspondingly, inheritors of intangible cultural heritage can show symbolism through design of derivatives, production and marketing process, such as integrate with ideas of cultural inheritance, cultural selfconfidence, local context and craftsmanship spirit in marketing and emphasize the spiritual value and symbolic value of derivatives of intangible cultural heritage in meeting consumers' needs to make consumers of derivatives of intangible cultural heritage produce greater sense of satisfaction and pride. Secondly, they can cooperate with universities and scientific research institutions to conduct researches on the symbol element of meta-culture of derivatives of intangible cultural heritage and its symbolical meanings and deposit consumers' emotional commitments through establishing product faith of intangible cultural heritage. Thirdly, they can carry out integrated innovation of the original symbols of intangible cultural heritage to strengthen the metal orientation of derivatives of intangible cultural heritage in consumer groups.

\section{Take Advantage of the Culture of Derivatives of Intangible Cultural Heritage to Elevate Consumers' Cultural Self- \\ Esteem}

Cultural self-esteem is the sublimation of cultural identity and shows consumers' attentions to derivatives of intangible cultural heritage and expects derivatives of intangible cultural heritage can achieve further integrated innovation in modern society. They reflect consumers' positive pursuit of cultural connotation, national emotions and group evaluation contained in the derivatives of intangible cultural heritage under Chinese context.

Inheritors of intangible cultural heritage and enterprise can enhance consumers' cultural self-esteem through elevating consumers' sense of pride towards the traditional culture and shaping the cultural brands of derivatives of intangible cultural heritage. Firstly, inheritors or enterprises must respond to the protection system at national, provincial, municipal and county levels, proactively participate in the logging of intangible cultural heritage list and constantly apply for lists of protecting intangible cultural heritage of higher levels to improve popularity and reputation. Secondly, they should endeavor to participate in CCTV Spring Festival Evening Gala, national festival activities of intangible cultural heritage and literary expo to show brand images and product connotation to audiences at home and abroad through platforms at higher level and shape cultural brands for derivatives of intangible cultural heritage. Finally, they can form the halo effect of the reputation of derivatives of intangible cultural heritage via "inviting", inviting renowned cultural workers, journalists and public figures to guide, visit and report in the manufacturing enterprises of derivatives of intangible cultural heritage and using the effects of key opinion leaders.

\section{CONCLUSION}

Dominique Desjeux (2014) proposes consumer goods are diversified with complete functions and integrate practicality, status symbol, interestingness, commemorative significance, aesthetic feeling and religious meaning [19]. For culture 
consumer goods, the significance of status symbol is often more important than its practical functions. As an attitude evaluation and emotional appeal, cultural identity can arouse consumers' memories and make products more humanized and have more social emotions and symbolic significance. Improving consumers' cultural identity can further enrich the marketing paths of derivatives of intangible cultural heritage, avail inheritors or enterprises in better grasping consumers' psychology and behaviors in order to improve market competitiveness. According to the basic property of derivatives of intangible cultural heritage like sociality, regionalism, symbol and culture, this research holds the opinion that consumers' cultural identity can serve as an entry point for the marketing of derivatives of intangible cultural heritage and has proposed marketing suggestions from product cognition, group affiliation, emotional commitment and cultural self-esteem on the basis of related researches on consumers' cultural identity, looking forward to providing reference for the emotional marketing of inheritors of intangible cultural heritage or cultural enterprises.

\section{REFERENCES}

[1] Ching Wan, Pony Yuen-Ga Chew. Cultural knowledge, category label, and social connections: Components of cultural identity in the global, multicultural context[J].Asian Journal of Social Psychology, 2013 (16): 247-259.

[2] Zheng Xiaoyun. Cultural Identity [M], Beijing: China Social Sciences Publishing House, 2008: 4. 郑晓云.文化认同论[M].北京: 中国社会 科学出版社, 2008: 4

[3] Dong Qing, Hong Yan. Research on Media Sport Contact and Chinese Cultural Identity [J], Journal of Beijing University of Physical Education, 2015, 38 (11): 43-49. 董青, 洪艳.媒介体育接触与中国文 化认同研究 $[\mathrm{J}]$.北京体育大学学报, 2015, 38 (11) : 43-49.

[4] Chi-Tsun Huang, Tsung-Chi Liu. Discussion on the Advertising Effect of Foreign Images under Cultural Identity-Take the Tide of Crazing for Japanese Pop Culture as an Example [J], Sun Yat-Sen Management Review, 2005 (6): 417-449. 黄吉村, 刘宗其.文化认同下异国形象广 告效果之探讨——哈日风潮为例 [J].中山管理评论, 2005（6）: 417-449.

[5] Brown T J, Barry $\mathrm{T}$ E, Dacin $\mathrm{P}$ A, et al. Spreading the word: Investigating antecedents of consumers' positive word-of-mouth intentions and behaviors in a retailing context [J]. Journal of the Academy of Marketing Science, 2005, 33(2): 123-138.

[6] Bagozzi R P, Dholakia U M. Antecedents and purchase consequences of customer participation in small group brand communities [J]. International Journal of research in Marketing, 2006, 23 (1): 45-61.

[7] Edwards M R, Peccei R. Organizational identification: Development and testing of a conceptually grounded measure[J]. European journal of work and organizational psychology, 2007, 16(1): 25-57.

[8] Harquail C V. Organizational identification and the "whole person": integrating affect, behavior, and cognition. In: D. Whetten \& P. Godfrey (eds) [C].Identity in organizations: Building theory through conversations, 1998.223-231.

[9] Ellemers N, Kortekaas P, Ouwerkerk J W. Self-categorisation, commitment to the group and group self-esteem as related but distinct aspects of social identity[J]. European journal of social psychology, 1999, 29(23): 371-389.

[10] Li Xiaocen, Zhu Xia. Traditional Crafts and Chinese Brand [J], Studies in Dialectics of Nature, 2017, 33(2): 98-104. 李晓岑, 朱霞.传统工艺 与中国品牌[J].自然辩证法研究, 2017, 33 (2) : 98-104.

[11] (France) Jean Baudrillard; translated by Xia Ying. Critique of Symbolic Politics [M], Nanjing: Nanjing University Press, 2015（法）让·鲍德里 亚著; 夏莹译.符号政治学批判[M].南京: 南京大学出版社, 2015.
[12] Liu Fei. Research on Cultural Symbols and the Diffusion of Intangible Cultural Heritage [J], Dongyue Tribune, 2014, 35(7): 147-150. 刘菲. 文 化符号与非物质文化遗产传播研究 [J].东岳论丛，2014，35（7）: 147-150.

[13] (France) Jean Baudrillard; translated by Liu Cheng Fu, Quan Zhigang Consumer Society [M], Nanjing: Nanjing University Press, November 2014（法）让·鲍德里亚著; 刘成富, 全志钢译.消费社会[M].南 京: 南京大学出版社, 2014.11

[14] Gomzina I. Multilayered cultural identity and the perception of the self [D].University of Jyväskylä, 2012.

[15] Pomian K. European identity: Historical fact and political problem. In: L. Ornstein and L. Breemer (eds) [C].Paleis Europa. Grote denkers over Europa, 2009.1-14.

[16] Daphna Oyserman. Social identity and self-regulation. In A. W. Kruglanski \& E. T. Higgins (Eds.), Social psychology: Handbook of basic principles [C]. New York: Guilford Press, 2007: 432-453.

[17] Xavier Matteucci. The tourist experience of intangible heritage — the case of flamenco consumers [D].Vienna: Modul University Vienna, 2015.

[18] Burton P G. Product Description of 'Human Cognition: Higher Brain Function \& the Science of Human Consciousness'[J]. Social Science Electronic Publishing, 2011.

[19] (France) Dominique Desjeux; translated by Deng Yun. Consumption [M], Beijing: Commercial Press, 2014: 122. （法）多米尼克・戴泽 著; 邓芸译.消费[M].北京: 商务印书馆, 2014: 122. 